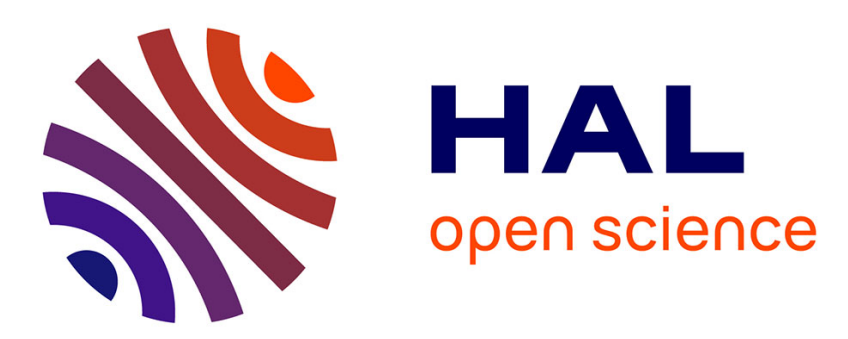

\title{
Application of SSCP-PCR fingerprinting to profile the yeast community in raw milk Salers cheeses
}

Cecile C. Callon, Céline C. Delbes, Frédérique Duthoit, Marie-Christine M.-C. Montel

\section{- To cite this version:}

Cecile C. Callon, Céline C. Delbes, Frédérique Duthoit, Marie-Christine M.-C. Montel. Application of SSCP-PCR fingerprinting to profile the yeast community in raw milk Salers cheeses. Systematic and Applied Microbiology, 2006, 29 (2), pp.172-180. 10.1016/j.syapm.2005.07.008 . hal-02659601

\section{HAL Id: hal-02659601 https://hal.inrae.fr/hal-02659601}

Submitted on 30 May 2020

HAL is a multi-disciplinary open access archive for the deposit and dissemination of scientific research documents, whether they are published or not. The documents may come from teaching and research institutions in France or abroad, or from public or private research centers.
L'archive ouverte pluridisciplinaire HAL, est destinée au dépôt et à la diffusion de documents scientifiques de niveau recherche, publiés ou non, émanant des établissements d'enseignement et de recherche français ou étrangers, des laboratoires publics ou privés. 


\title{
Application of SSCP-PCR fingerprinting to profile the yeast community in raw milk Salers cheeses
}

\author{
Cécile Callon*, Céline Delbès, Frédérique Duthoit, Marie-Christine Montel \\ Unité de Recherches Fromagères, INRA, 36 rue de Salers, F-15000 Aurillac, France
}

Received 23 June 2005

\begin{abstract}
Bacteria and yeasts are important sensory factors of raw-milk cheeses as they contribute to the sensory richness and diversity of these products. The diversity and succession of yeast populations in three traditional Registered Designation of Origin (R.D.O.) Salers cheeses have been determined by using phenotypic diagnoses and Single-Strand Conformation Polymorphism (SSCP) analysis. Isolates were identified by phenotypic tests and the sequencing of the D1-D2 domains of the 26S rRNA gene. Ninety-two percent of the isolates were identified as the same species in both tests. Yeast-specific primers were designed to amplify the V4 region of the 18S rRNA gene for SSCP analysis. The yeast species most frequently encountered in the three cheeses were Kluyveromyces lactis, Kluyveromyces marxianus, Saccharomyces cerevisiae, Candida zeylanoides and Debaryomyces hansenii. Detection of less common species, including Candida parapsilosis, Candida silvae, Candida intermedia, Candida rugosa, Saccharomyces unisporus, and Pichia guilliermondii was more efficient with the conventional method. SSCP analysis was accurate and could be used to rapidly assess the proportions and dynamics of the various species during cheese ripening. Each cheese was clearly distinguished by its own microbial community dynamics.
\end{abstract}

(C) 2005 Elsevier GmbH. All rights reserved.

Keywords: Yeasts; Dynamics; SSCP; 18S rDNA genes; Salers cheese

\section{Introduction}

Bacteria and yeasts are an important determinant of the quality of cheeses made from raw milk because they enhance the richness and diversity of the taste of these products. Bacteria alone cannot explain the diversity of the sensorial properties of cheese [8,9]. A comprehensive study on yeast communities in cheeses could help to explain how the sensory qualities of cheeses develop. Several molecular methods are available for microbial

\footnotetext{
*Corresponding author. Tel.: + 33471456410 ; fax: +33471456413 .

E-mail address: callon@clermont.inra.fr (C. Callon).
}

identification but only a few have been applied to yeasts isolated from cheeses. These methods include restriction fragment length polymorphism (RLFP) analysis of Intergenic Transcribed Spacers (ITS) [21], randomly amplified polymorphic DNA (RAPD) [1,22], and 26S rRNA gene sequencing with primers NL1 and NL4 [5]. These culture-dependent methods are now being replaced by direct molecular methods without culture. Indeed, Temperature Gradient Gel Electrophoresis (TGGE) has been used to profile wine yeasts [12] and Denaturing Gradient Gel Electrophoresis (PCR-DGGE) has been used to evaluate yeast biodiversity in raw milk [5]. By applying these methods, it is possible to evaluate the dynamics of yeast populations. 
The objective of this study was to evaluate the diversity of yeasts and their dynamics during ripening in three different raw-milk RDO Salers cheese by combining a direct molecular approach relying on the 18S rDNA analysis by Single-Strand Conformation Polymorphism (SSCP) and phenotypic and molecular identification of isolates of the same cheeses. The SSCP methodology used is based on the direct analysis of 18S rRNA gene pool, after PCR amplification and separation in non-denaturing conditions. It provides a rapid fingerprint of a complex microbial community including dead and alive microbial cells. SSCP has been applied to study microbial communities in water [17], in compost of organic agricultural substrate [20], and in anaerobic digestors [16,29]. This technique has also been used in clinical microbiology to rapidly differentiate bacteria from blood culture [26]. SSCP analysis has never been applied to cheese yeast population but it has been used to investigate bacterial dynamics in the same Salers cheeses $[4,9]$.

\section{Materials and methods}

\section{Cheeses samples}

Cheese samples were obtained from three farms (A, B, and $\mathrm{C}$ ), in the Salers cheese production area and selected for different sensory features. Salers cheeses were exclusively produced with raw milk stored in a wooden container (the "gerle"). Milk was neither heated nor refrigerated after milking. No starter culture was added. Samples from three cheeses were collected 1 day after cheesemaking and after 8, 30, 90 and 150 days of ripening. Sub-samples were stored at $-80^{\circ} \mathrm{C}$ until analyzed.

\section{Total DNA isolation from cheese samples}

One gram of cheese was mixed with $1 \mathrm{ml}$ of $4 \mathrm{M}$ guanidine thiocyanate- $100 \mathrm{mM}$ Tris $(\mathrm{pH} \mathrm{7.5)}$ and $125 \mu 1$ of $10 \% \mathrm{~N}$-lauroylsarcosine and blended with a reciprocating shaker (MM2000; Kurt Retsch) and frozen at $-80^{\circ} \mathrm{C}$. Phenol/chloroform extractions were used to extract total DNA from samples [9]. The DNA solutions were stored at $-20^{\circ} \mathrm{C}$.

\section{Primer design}

A set of specific primers was developed by comparing gene sequences encoding 18S rRNA (18S rDNA). These sequences, characteristic of most yeast species found in dairy products (26 different species), were aligned by using Multalin version 5.4.1 (multiple sequence alignment with hierarchical clustering) [6]. We designed two conserved primers flanking a variable region in the V4 portion of the 18S rDNA: forward primer Lev1 (5'-
AGTTGTTGCAGTTAAAAAG-3') and reverse primer Lev2 (5'-CCTATTAATCATTACGA-3'). Primer specificity was tested as part of the Ribosomal Database Project (RDP) [18] and Blast, and was experimentally tested with a series of 15 reference yeast strains and Salers isolates (Table 1), with Geotrichum candidum a positive control and several species of Lactobacillus, Leuconostoc, Lactococcus and Pediococcus as negative controls.

\section{PCR-SSCP amplification and SSCP electrophoresis}

The primers used to amplify the $270 \mathrm{bp}$ of the $18 \mathrm{~S}$ rRNA gene were labeled with $5^{\prime}$-hexachloro derivative of fluorescein (HEX: Lev1) and 5'-fluorescein phosphoramidite (NED: Lev2), purchased from Applied Biosystems (Courtaboeuf, France). PCR was performed in a total volume of $25 \mu$ containing $1 \times \mathrm{Ez}$ buffer (Applied Biosystems), $2.5 \mathrm{mM}$ of $\mathrm{Mn}(\mathrm{OAc})_{2}$ solution (Applied Biosystems), $0.5 \mu \mathrm{M}$ of each primer, $0.5 \mathrm{mM}$ dNTPs, $2 \mathrm{U}$ of $\mathrm{rTth}$ polymerase (Applied Biosystems) and $10 \mathrm{ng}$ of the extracted DNA. The thermocycler was programmed with an initial denaturing step at $94^{\circ} \mathrm{C}$ for $5 \mathrm{~min}$, followed by 30 cycles of $94{ }^{\circ} \mathrm{C}$ for $30 \mathrm{~s}, 47^{\circ} \mathrm{C}$ for $30 \mathrm{~s}$ and $72{ }^{\circ} \mathrm{C}$ for $60 \mathrm{~s}$, with a final extension at $72^{\circ} \mathrm{C}$ for $7 \mathrm{~min}$. The amplification products were resolved on a $1 \%$ agarose gel and stained with ethidium bromide. PCR products were purified with a StrataPrep ${ }^{\text {TM }}$ PCR purification Kit (Stratagene, Saint Quentin en Yvelines, France) following the manufacturer's instructions and then analyzed by SSCP [9].

\section{Cheese 18S rDNA amplification and cloning}

The 18S rDNA gene was amplified with unlabeled primers Lev1 and Lev2 from two different cheeses. Each reaction tube contained PfuUltra buffer $1 \times$ (Stratagene, Amsterdam, The Netherlands), $0.2 \mathrm{mM}$ of each $\mathrm{dNTP}, 0.5 \mu \mathrm{M}$ of each primer, $10 \mathrm{ng}$ of purified DNA and $1.25 \mathrm{U}$ of PfuUltra polymerase (Stratagene) adjusted to a total volume of $25 \mu$ l. After initial denaturation at $94{ }^{\circ} \mathrm{C}$ for $5 \mathrm{~min}, 30$ cycles were performed at $94{ }^{\circ} \mathrm{C}$ for $30 \mathrm{~s}, 47^{\circ} \mathrm{C}$ for $30 \mathrm{~s}$ and $72^{\circ} \mathrm{C}$ for $60 \mathrm{~s}$, followed by a final extension step of $72{ }^{\circ} \mathrm{C}$ for $7 \mathrm{~min}$. PCR products were ligated in the pCR4Blunt-TOPO vector and transformed into Escherichia coli TOPO10 OneShot cells as specified by the manufacturer (Invitrogen, Cergy Pontoise, France).

\section{Identification of SSCP peaks}

To assign SSCP pattern peaks to species, the 18S rRNA gene clone libraries were analyzed by SSCP. SSCP-PCR was performed on the clones and the resulting peaks were compared with the SSCP patterns of the cheese. Variable 
Table 1. SSCP analysis of $18 \mathrm{~S}$ rRNA genes of 15 yeast strains and Salers isolates (three repetitions)

\begin{tabular}{|c|c|c|c|c|c|}
\hline \multirow[t]{2}{*}{ Species } & \multirow[t]{2}{*}{ Strains } & $\mathrm{A}^{\mathrm{a}}$ & \multirow[t]{2}{*}{ Species } & \multirow[t]{2}{*}{ Strains } & \multirow{2}{*}{$\frac{\mathrm{B}^{\mathrm{b}}}{\text { Elution in scan }}$} \\
\hline & & Elution in $\operatorname{scan}^{\mathrm{c}}$ & & & \\
\hline C. catenulata & $\mathrm{CBS}^{\mathrm{d}} 565$ & 7246 & C. catenulata & CBS 565 & 7378 \\
\hline$Y$. lipolytica & $\mathrm{CLIB}^{\mathrm{e}} 183$ & 7327 & $Y$. lipolytica & CLIB 183 & 7450 \\
\hline C. rugosa & CLIB 613 & 7780 & C. parapsilosis & Salers isolate & 7948 \\
\hline D. hansenii var hansenii & CLIB 197 & 7792 & D. hansenii var hansenii & CLIB 197 & 7985 \\
\hline C. intermedia & CBS 572 & 7796 & C.intermedia & CBS 572 & 7993 \\
\hline C. krusei & CLIB 308 & 7858 & C. krusei & CLIB 308 & 8078 \\
\hline P. membranifaciens & CLIB 212 & 7859 & P. membranifaciens & CLIB 212 & 8089 \\
\hline P. fermentans & CLIB 198 & 7883 & C. rugosa & CLIB 613 & 8117 \\
\hline C. parapsilosis & Salers isolate & 7949 & P. fermentans & CLIB 198 & 8125 \\
\hline C. silvae & Salers isolate & 8021 & C. zeylanoides & CLIB 199 & 8276 \\
\hline Kl. lactis & CLIB 196 & 8060 & S. dairenensis & CLIB 175 & 8336 \\
\hline Kl. marxianus & CLIB 282 & 8093 & T. delbrueckii & CLIB 230 & 8339 \\
\hline S. cerevisiae & CLIB 227 & 8120 & Kl. lactis & CLIB 196 & 8339 \\
\hline T. delbrueckii & CLIB 230 & 8129 & S. cerevisiae & CLIB 227 & 8393 \\
\hline S. dairenensis & CLIB 175 & 8129 & S. unisporus & CLIB 234 & 8402 \\
\hline C. zeylanoides & CLIB 199 & 8174 & Kl. marxianus & CLIB 282 & 8411 \\
\hline S. unisporus & CLIB 234 & 8204 & C. silvae & Salers isolate & 8479 \\
\hline
\end{tabular}

C. $=$ Candida, $\mathrm{S} .=$ Saccharomyces, $\mathrm{Kl} .=$ Kluyveromyces, $\mathrm{T} .=$ Torulaspora, $\mathrm{P} .=$ Pichia.

${ }^{a}$ Elution on HEX-labeled forward strand.

${ }^{\mathrm{b}}$ Elution on reverse strand NED.

${ }^{\mathrm{c}}$ Unit of GeneScan software on the SSCP pattern. Elution values represent the average of three analyses. Standard deviation values always $<5$.

${ }^{\mathrm{d}}$ Central Bureau vor Schimmelcultures, Neederland.

${ }^{\mathrm{e}}$ Collection de Levures d'Intérêt Biotechnologique. Grignon, France.

regions of the 18S rRNA gene from 15 representative clones were sequenced by using dye-terminator cycle sequencing ready reaction kits with Taq DNA polymerase and primers Lev1 and Lev2. Yeast reference strains and isolates from cheeses also were analyzed by SSCP to create a species pattern database.

\section{Isolation and identification of isolates}

Yeasts of the same three cheeses were counted from fresh sample plates. Yeast colonies were grown on an Oxytetracycline Glucose Agar base (OGA) (Biokar Diagnostics, Beauvais, France) supplemented with oxytetracycline $(1 \mathrm{mg} / \mathrm{ml})$. One hundred and two colonies were selected from plates at different times of ripening and purified in Yeast Extract Peptone Glucose (YPG) broth (yeast extract $10 \mathrm{~g}$, bacto-peptone $20 \mathrm{~g}$, glucose $40 \mathrm{~g}$ and demineralized water to $1000 \mathrm{ml}, \mathrm{pH}$ 5.2). On each plate, colonies were selected based on their aspect diversity. The total of picked colonies per plate was always equal to the root square of total number. All cultures were frozen $\left(-80^{\circ} \mathrm{C}\right)$ before identification.

Yeast isolates were identified by using the morphological, biochemical and physiological characters of Kurtzman and Fell [14] and assigned to a species with the dichotomous key of Barnett et al. [3]. Carbon compound assimilation was determined with the API ID
32C kit (Bio Merieux). All tests were performed in duplicate for non-identified isolates.

Molecular identification was performed by sequencing the 26S rRNA gene. Total DNA was extracted from cultures of each isolate according to the miniprep protocol of Hoffman and Winston [13]. The D1/D2 domain of the 26S rRNA gene was amplified by PCR, using primers NL1 and NL4 as described by Kurtzman and Robnett [15]. The sequencing reactions of the forward and reversed strands were carried out with a dye-terminator cycle sequencing ready reaction kit (Applied Biosystems) with AmpliTaq DNA polymerase FS and the NL1 and NL4 primers, respectively. The reaction products were sequenced with an automated DNA sequencer ABI PRISM 310 (Applied Biosystems) and analyzed with sequencing analysis software (Applied Biosystems). The partial 26S rDNA sequences obtained were compared to the sequences deposited in the GenBank DNA database, using the BLAST algorithm [2]. The percentage of similarity with the DNA sequences deposited was determined.

\section{Results and discussion}

\section{Discrimination of yeast species by SSCP analysis}

To create a species pattern database, the SSCP patterns of pure cultures (15 culture collection strains 
belonging to different species frequently encountered in dairy products [11] were determined. In the same way, SSCP patterns of two strains identified below and originating from microbial analysis of the same Salers cheeses were determined too. 18S rDNA was amplified three times with the two primers Lev1 labeled with HEX and Lev2 labeled with NED. Each strain always produced the same pattern, thus confirming the reproducibility of PCR-SSCP analysis. Differences between the forward and reverse strand of the same strain is due to the fact that SSCP distinguishes DNA fragments according to their sequence on basis of single-strand conformation. Taking both strands into account, nearly all species were easily differentiated by SSCP analysis (Table 1). For example, the HEX-labeled strand from Torulaspora delbrueckii and Saccharomyces dairenensis had a similar pattern, but these two species could be distinguished by analyzing the NED-labeled strand. A similar result was obtained with Candida krusei and Pichia membranifaciens. T. delbrueckii and Kluyveromyces lactis had NED-labeled strands that were similar but could be differentiated by analyzing the HEXlabeled strand. Analysis of both strands generally was necessary to distinguish all 17 species.

\section{Direct fingerprinting of yeast diversity in different Salers cheeses by SSCP-PCR}

The reproducibility of the PCR-SSCP approach was evaluated by repeating the DNA analysis of a cheese yeast community two times. The two profiles of the same cheese aligned, with the same variations in each peak area (Fig. 1). The yeast community fingerprints from three different cheeses (A, B and C) were evaluated after 8 and 150 days of ripening (Fig. 2, HEX-labeled strand). The 8-day SSCP patterns differed in the number of peaks per sample. After 150 days of ripening, the fingerprints of the same cheese samples had different SSCP-PCR profiles. Some peaks appeared or disappeared in the course of ripening or differed with respect to their size.

\section{Identification of peaks}

To identify the sequences corresponding to peaks in the different patterns, a 260-clone library of $18 \mathrm{~S}$ rRNA genes from the DNA extracted from cheese A at 150 days (Fig. 2 top right) was constructed and each clone was analyzed by SSCP. All of the clones corresponded to one of the four dominant peaks (a, b, d, e). For each peak, five co-eluting clones were sequenced and identified based on the similarity to $18 \mathrm{~S}$ rDNA sequences deposited in Genbank. SSCP peak identification also relied on the elution of reference strains and yeast isolates (Table 2). Based on the sequence of the clone

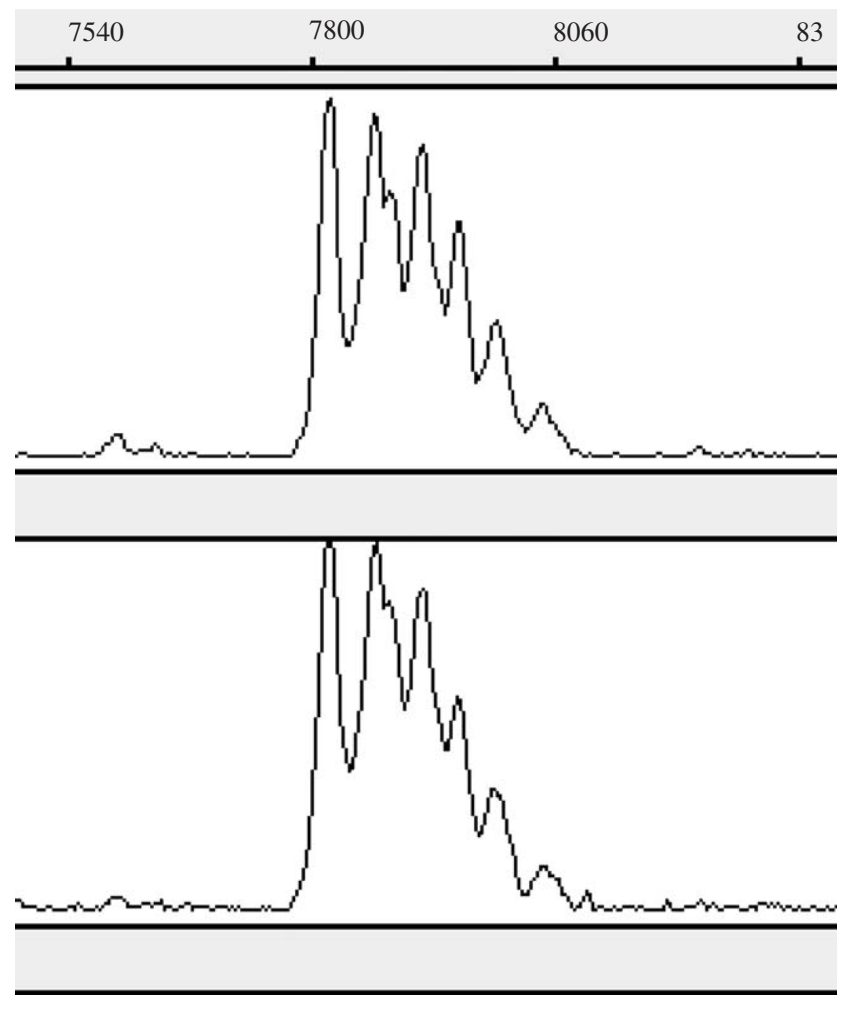

Fig. 1. Reproducibility of PCR-SSCP analysis as assessed by repeating two times the DNA analysis of a cheese yeast community, forward primer labeled with HEX.

18S rRNA gene and co-elution with reference strains and isolates, peak a was $K$. lactis, peak b was $K$. marxianus and peak d was $C$. zeylanoides. Peak e coeluted with clones identified as $D$. hansenii var. hansenii and $D$. hansenii var. fabryii with a same percentage of similarity with strains in Genbank database. However, peak e had a different pattern to that of the D. hansenii var. hansenii type strain. Peaks $\mathrm{c}$ and $\mathrm{h}$ co-eluted, respectively, with the reference strains for $S$. cerevisiae and $S$. unisporus. Peaks $\mathrm{f}$ and g co-eluted with isolates identified as $C$. parapsilosis and $C$. silvae. The other peaks present in patterns (Fig. 2) represent less than $1 \%$ of total area or in term of absolute area, less than the value considered as the background and were then considered as non-significant.

\section{Dynamics of yeast populations in cheeses}

To analyze the SSCP profiles of cheeses, the peak ratio (the proportion of one peak to the total area of all of the peaks) was calculated in each sample and used as an indicator of changes within the yeast populations. Considering the entire sample times (Table 3), the peaks corresponding to $K$. lactis, $K$. marxianus, $S$. cerevisiae, $D$. hansenii and $C$. zeylanoides were systematically present in the SSCP patterns of all three cheeses. Peaks corresponding to $C$. parapsilosis, $C$. silvae and $S$. 
$8 \mathrm{~d}$
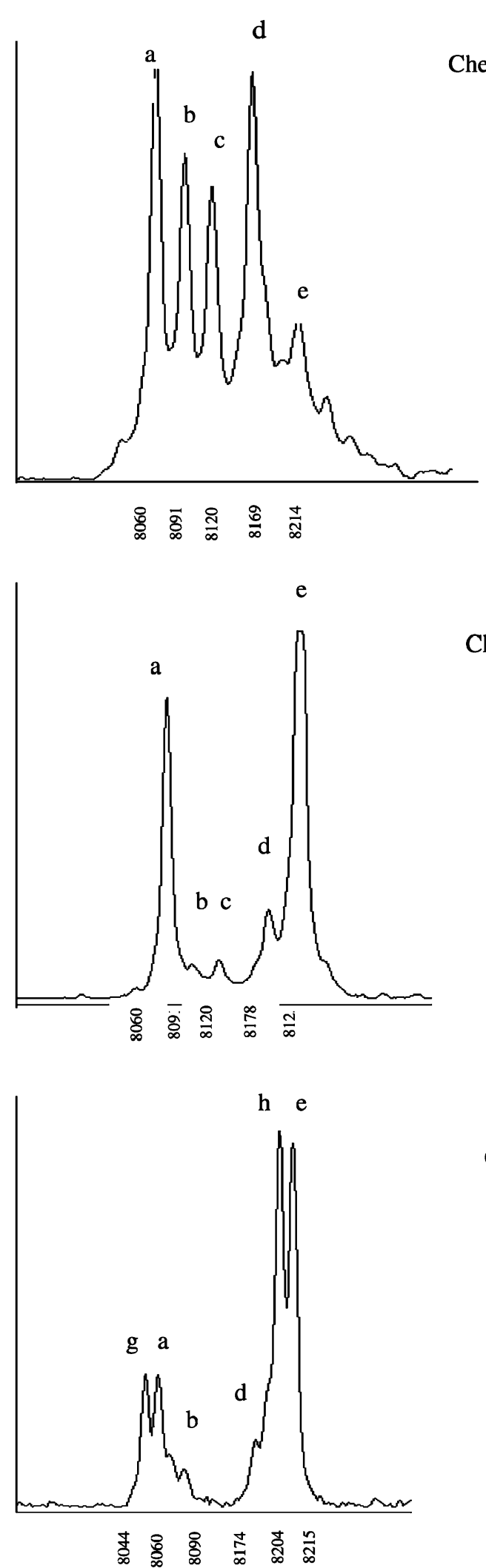

$150 \mathrm{~d}$

a
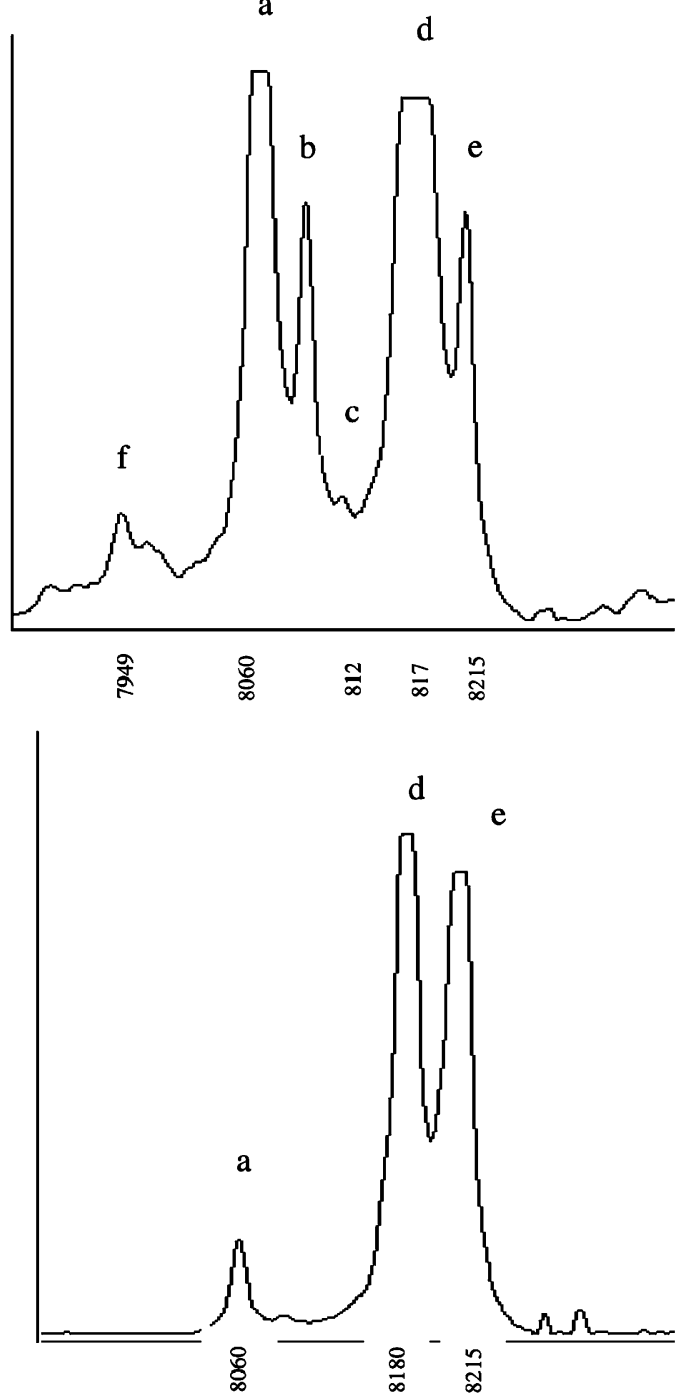

Cheese B
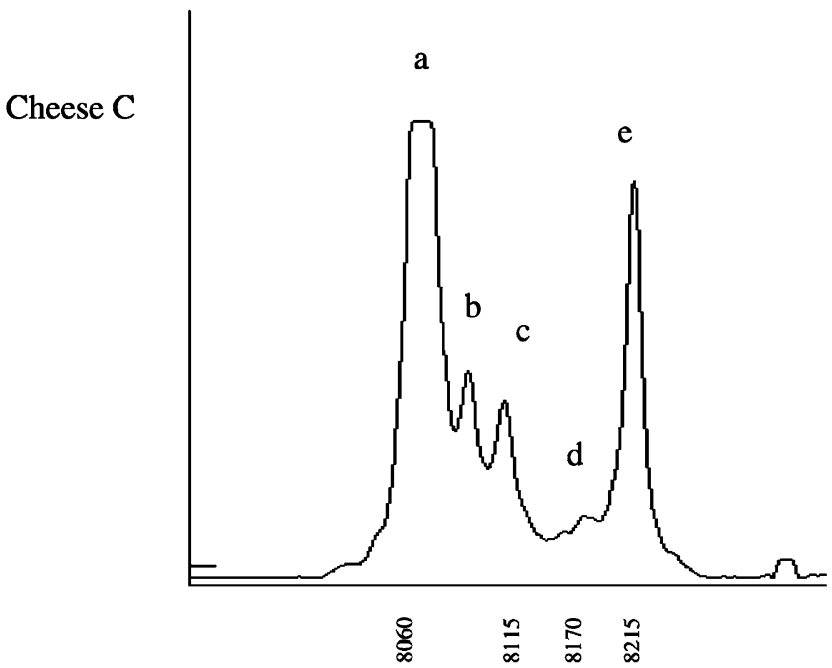

Fig. 2. SSCP patterns of PCR-amplified 18S rRNA gene fragments from yeast communities of three cheeses A, B and C at 8 and $150 \mathrm{~d}$ of ripening, forward primer labeled with HEX, $Y$-axis: fluorescence. $X$-axis: elution in scans (unit of Genescan software). The position and labeling of peaks discussed in Tables 2 and 3 and in text are indicated. 
Table 2. Identification of peaks obtained from SSCP pattern of the yeast community (18S rDNA) by comparison with patterns of reference strains, clones, and isolates

\begin{tabular}{|c|c|c|c|}
\hline \multirow[b]{2}{*}{ Peaks (Fig. 2) } & \multicolumn{2}{|c|}{ Assignation according to the elution of: } & \multirow[b]{2}{*}{ GenBank accession no } \\
\hline & $\begin{array}{l}\text { Reference and isolate SSCP } \\
\text { patterns }^{\mathrm{a}}\end{array}$ & $\begin{array}{l}\text { Corresponding clones showing more } \\
\text { than } 99 \% \text { identity }^{\text {b }}\end{array}$ & \\
\hline $\mathrm{a}$ & K. lactis & K. lactis & CSP508583 \\
\hline $\mathrm{b}$ & K. marxianus & K. marxianus & AF201299 \\
\hline $\mathrm{c}$ & S. cerevisiae & & \\
\hline $\mathrm{d}$ & C. zeylanoides & C. zeylanoides & AB013509.1 \\
\hline $\mathrm{e}$ & & $\begin{array}{l}\text { D. hansenii var. Hansenii } \\
\text { D. hansenii var. fabryii }\end{array}$ & AB106349 \\
\hline f & C. parapsilosis & & \\
\hline g & C. silvae & & \\
\hline $\mathrm{h}$ & S. unisporus & & \\
\hline
\end{tabular}

${ }^{\mathrm{a} C}$., Candida, S., Saccharomyces, K., Kluyveromyces.

${ }^{\mathrm{b}}$ Percentage of identical nucleotides in the sequence retrieved from the clone and the sequences of the closest relatives found in GeneBank and RDP database.

Table 3. Evolution of the peak ratio of the SSCP patterns of the three cheeses (A, B, and C) at different times of ripening

\begin{tabular}{|c|c|c|c|c|c|c|c|c|c|c|c|c|c|}
\hline \multirow[t]{4}{*}{ Peaks } & \multirow[t]{4}{*}{ Species } & \multicolumn{12}{|c|}{ Peak ratios $(\%)^{\mathrm{a}}$} \\
\hline & & \multicolumn{4}{|c|}{ Cheese A } & \multicolumn{4}{|c|}{ Cheese B } & \multicolumn{4}{|c|}{ Cheese C } \\
\hline & & \multicolumn{4}{|c|}{ Stages of ripening } & \multicolumn{4}{|c|}{ Stages of ripening } & \multicolumn{4}{|c|}{ Stages of ripening } \\
\hline & & $8^{b}$ & 30 & 90 & 150 & 8 & 30 & 90 & 150 & 8 & 30 & 90 & 150 \\
\hline$f$ & C. parapsilosis & & & & 4 & & & & & & & & \\
\hline $\mathrm{g}$ & C. silvae & 1.8 & & & & & & & & 11 & & & \\
\hline $\mathrm{a}$ & K. lactis & 23 & 22 & 13 & 30 & 28 & 43.4 & 33 & 5.0 & 11 & 60 & 66 & 48 \\
\hline b & K. marxianus & 20 & 25 & 4.2 & 13 & 3.8 & 4.8 & 4.6 & & 3.6 & 9.4 & 12 & 12 \\
\hline $\mathrm{c}$ & S. cerevisiae & 16 & 2.8 & 5.6 & 3 & 4.7 & 9.9 & 18 & 0.5 & & 11.5 & 15 & 13 \\
\hline $\mathrm{d}$ & C. zeylanoides & 29 & 30 & 39 & 39 & 12 & 7.3 & 17 & 46 & 6.2 & 2.7 & 0.7 & 4 \\
\hline $\mathrm{h}$ & S. unisporus & & & & & & & 14 & & 38 & & & \\
\hline e & D. hansenii & 11 & 20 & 37 & 12 & 53 & 35 & 9.7 & 47 & 30 & 17 & 6.9 & 23 \\
\hline \multicolumn{14}{|c|}{ Total yeast counts $(\mathrm{ufc} / \mathrm{g})^{\mathrm{c}}$} \\
\hline & & 5.53 & 5.71 & 5.38 & 6.68 & 5.85 & 5.83 & 4.95 & 4.08 & 6.36 & 6.20 & 5.48 & 4.52 \\
\hline
\end{tabular}

${ }^{a}$ The percent ratio was calculated as the area of one peak to the sum of the area of all peaks of the pattern $\times 100$.

${ }^{\mathrm{b}}$ Stage of ripening expressed in days.

${ }^{\mathrm{c}}$ Counts on OGA medium + oxytetracyclin.

unisporus were only detected in some cheese at one time. The yeast community of cheese A had a high peak ratio for $C$. zeylanoides, which increased throughout the ripening period and had a peak for C. parapsilosis, which was detected only at 150 days. The yeast community of cheese B was dominated by $D$. hansenii after 8 days, but $C$. zeylanoides was dominant at 150 days. In this cheese, $S$. unisporus was not detected before 90 days. The high peak ratios for $C$. silvae and $S$. unisporus after 8 days and their lack of detection later in the ripening period characterized the yeast community of cheese C. During the ripening of this cheese $K$. lactis became dominant.
Dynamics of yeast populations as presented in Table 3 revealed changes in the relative abundance of DNA sequences in the yeast community. Cheese is a closed system and the number of species in the cheese core presumably does not increase throughout the ripening period. Thus, changes in peak ratios are not likely to be due to preferential PCR amplification of some sequences, but rather to changes in the balance of $18 \mathrm{~S}$ rRNA genes of the species present. The changes of yeast population balance may result from many "events" such as development of one species or lysis of certain cells and degradation of DNA. The total count on OGA medium (Table 3) indicated that the yeast population level 
decreased during ripening for two productions. This argues for a lysis of cells but does not provide information on the growth of each yeast species.

\section{Comparison with Salers isolates identification}

One hundred and two isolates were selected from the same three cheeses for identification based on phenotypic tests and 26S rRNA sequences. The majority of these partial $26 \mathrm{~S}$ rRNA sequences were $>98 \%$ similar to sequences in GenBank. Isolate identification by phenotypic testing and 26S rRNA gene sequencing was congruent for $92 \%$ of the isolates. Eight isolates assigned to $C$. zeylanoides, $C$. parapsilosis, and $K$. lactis based on their 26S rDNA sequences were difficult to identify by phenotypic testing because their carbon compound assimilation profiles were not consistent with those of any identified species.

This species inventory, based on isolate identification, was compared with that obtained by the cloning and SSCP methods (Table 4). Both approaches detected $K$. lactis, $K$. marxianus, $C$. zeylanoides, $S$. cerevisiae and $C$. parapsilosis. K. lactis and $K$. marxianus frequently are present in many types of cheese [7,10,23,25,27]. $C$. zeylanoides often is isolated from Portuguese ewe's cheese [19] and raw milk [5]. S. cerevisiae has been isolated from raw milk [5] and a number of cheeses including Mozarella [7], Gouda [27], Cheddar [28], Camembert [23]. C. parapsilosis was found in Italian raw milk [5].

Table 4. Comparison of presence of different species in three cheeses A, B, and $\mathrm{C}$ (all times at once) detected using identification of 94 isolates or SSCP method

\begin{tabular}{|c|c|c|c|c|c|c|}
\hline \multirow[t]{2}{*}{ Species $^{\mathrm{a}}$} & \multicolumn{2}{|c|}{ Cheese A } & \multicolumn{2}{|c|}{ Cheese B } & \multicolumn{2}{|c|}{ Cheese C } \\
\hline & Isolates & SSCP & Isolates & $\mathrm{SSCP}$ & Isolates & $\mathrm{SSCP}$ \\
\hline Kl. lactis & 9 & $\mathrm{~d}^{\mathrm{b}}$ & 12 & $\mathrm{~d}$ & 9 & $\mathrm{~d}$ \\
\hline Kl. marxianus & 6 & $\mathrm{~d}$ & 1 & $\mathrm{~d}$ & 7 & $\mathrm{~d}$ \\
\hline S. cerevisiae & 2 & $\mathrm{~d}$ & 3 & $\mathrm{~d}$ & 7 & $\mathrm{~d}$ \\
\hline C. zeylanoides & 6 & $\mathrm{~d}$ & 2 & $\mathrm{~d}$ & 2 & $\mathrm{~d}$ \\
\hline D. hansenii & 3 & $\mathrm{~d}$ & 3 & $\mathrm{~d}$ & & $\mathrm{~d}$ \\
\hline C. intermedia & 3 & $\mathrm{nd}^{\mathrm{c}}$ & 2 & nd & 3 & nd \\
\hline C. silvae & & $\mathrm{d}$ & & & 3 & $\mathrm{~d}$ \\
\hline P. guilliermondii & & & 1 & & & \\
\hline C. parapsilosis & 5 & $\mathrm{~d}$ & & & & \\
\hline C. tropicalis & & & & & 1 & nd \\
\hline C. rugosa & & & 1 & nd & 1 & nd \\
\hline S. unisporus & & & 1 & $\mathrm{~d}$ & 1 & nd \\
\hline Total & 34 & & 26 & & 34 & \\
\hline
\end{tabular}

\footnotetext{
${ }^{a}$ Identification by $26 \mathrm{~S}$ DNA sequencing in agreement with phenotypic tests.

${ }^{b}$ Detected

${ }^{\mathrm{c}}$ Non-detected.
}

The community composition determined by the SSCP method and by isolate identification differed in the detection of $D$. hansenii, $C$. silvae and $S$. unisporus. Neither $D$. hansenii nor $C$. silvae were detected by isolate identification but they were detected by SSCP. $D$. hansenii often is isolated from many types of cheeses. Several isolates were identified as $S$. unisporus whereas this species was seen in only on a few of the SSCP profiles. This species was found in Armada cheese [25]. We identified isolates of $C$. intermedia, C. rugosa, $C$. tropicalis, and $P$. guilliermondii from RDO Salers cheese by phenotypic identification that were not detected by SSCP. These species have been found sporadically in some dairy products: $P$. guilliermondii and $C$. rugosa were found in Italian raw milk [5]. Y. lipolytica previously was isolated from Feta cheese [10], Armada cheese [25], Gouda and Cheddar [27,28] but was not detected in Salers cheese by either method that we used.

The differences in community composition detected by each method reflect the strengths and limitations of each method. Community composition determined by identifying isolates depends on the number of isolates picked from the counting plates and the method used to select those isolates. If the number of isolates selected is too low, then the collection will be not representative of the population. Based on our results, this culturedependent method is sensitive enough to detect species that are not detected by SSCP analysis. These results are consistent with those of Cocolin et al. [5], who found that more yeast species were detected in raw milk by a culture method than by DGGE. The difficulty in identifying less-common species by direct PCR-based molecular methods (SSCP, T(D)GGE) may be attributed to preferential amplification of dominant populations by PCR and/or to the bias of the SSCP detection system towards the most frequent sequences, i.e. the fluorescent signal of a less common sequence may not be easily distinguished from background noise. This can explain why $S$. unisporus was only detected after 90 days. At the beginning of ripening, it may be present but subdominant. But the SSCP method is more accurate and rapid to follow dominant population's dynamics.

This study shows the value of combining several methods (identification of isolates and direct molecular method such as SSCP) to describe cheese yeast communities. The use of multiple approaches to characterize populations has not commonly been used to analyze dairy products except by Cocolin et al. [5] who profiled yeast populations in raw milk by using both PCR-DGGE and isolate identification. To our knowledge, this is the first description of the dynamics of yeast communities in cheese by a culture-independent method.

The SSCP method quickly provides an image of the yeast population and permits the visual comparison of several samples. Thus PCR-SSCP is a powerful tool for tracking yeast community composition in fermented 
dairy products. Each of the three cheeses had its own community composition profile. These results are consistent with those of Suzzi et al. [24] who also reported that yeast composition could change during the ripening period.

To complete this study, it would be necessary to determine the 18S rRNA SSCP profile, so as to assess the activity of yeasts during ripening. It will then be possible to integrate all these data with those obtained by Duthoit [8] on the bacterial community of this cheese, to better explain their sensorial properties.

\section{Acknowledgements}

We thank the Salers cheeses productions and the "Pôle Fromager AOC Massif Central" for their interest and Philip Rousseau-Cunningham for English proofreading.

\section{References}

[1] C. Andrighetto, E. Psomas, N. Tzanetakis, G. Suzzi, A. Lombardi, Randomly amplified polymorphic DNA (RAPD) PCR for the identification of yeasts isolated from dairy products, Lett. Appl. Microbiol. 30 (2000) 5-9.

[2] S.F. Altschul, W. Gish, W. Miller, E.W. Myers, D.J. Lipman, Basic local alignment search tool, J. Mol. Biol. 215 (1990) 403-410.

[3] J.A. Barnett, R.W. Payne, D. Yarrow, Yeasts: Characteristics and identification, second ed, Cambridge University Press, Cambridge, England, 1990.

[4] C. Callon, L. millet, M.C. Montel, Diversity of lactic acid bacteria isolated from AOC salers cheese, J. Dairy Res. 71 (2004) 231-244.

[5] L. Cocolin, D. Aggio, M. Manzano, C. Cantoni, G. Comi, An application of PCR-DGGE analysis to profile the yeast populations in raw milk, Int. Dairy J. 12 (2002) 407-411.

[6] F. Corpet, Multiple sequence alignment with hierarchical clustering, Nucl. Acids Res. 16 (1998) 10881-10890.

[7] S. Coppola, G. Blaiotta, D. Ercolini, G. Moschetti, Molecular evaluation of microbial diversity occurring in different types of Mozzarella cheese, J. Appl. Microbiol. 90 (2001) 414-420.

[8] F. Duthoit, C. Callon, L. Tessier, M.C. Montel, Relationships between sensorial characteristics and microbial dynamics in "Registered Designation of Origin" Salers cheese, J. Appl. Microbiol. 98 (2005) 1198-1208.

[9] F. Duthoit, J.J. Godon, M.C. Montel, Bacterial community dynamics during production of Registered Designation of Origin Salers cheese as evaluated by $16 \mathrm{~S}$ rRNA gene single strand conformation polymorphism analysis, Appl. Environ. Microbiol. 69 (2003) 3840-3848.

[10] M.E. Fadda, S. Cosentino, M. Deplano, F. Palmas, Yeast populations in Sardinian feta cheese, Int. J. Food Microbiol. 69 (2001) 153-156.
[11] G.H. Fleet, Yeasts in dairy products, J. Appl. Bacteriol. 68 (1990) 199-211.

[12] S. Hernan-Gomez, J.C. Espinosa, J.F. Ubeda, Characterization of wine yeasts by temperature gradient gel electrophoresis (TGGE), FEMS Microbiol. Lett. 193 (2000) 45-50.

[13] C.S. Hoffman, F. Winston, A ten minute DNA preparation from yeast efficiently releases autonomous plasmids for transformation of Escherichia coli, Gene 57 (1987) 267-272.

[14] C.P. Kurtzman, J.W. Fell, The Yeasts: A Taxonomic Study, fouth ed, Elsevier Science, Amsterdam, 1998.

[15] P. Kurtzman, C.J. Robnett, Identification of clinically important ascomycetous yeasts based on nucleotide divergence in the $5^{\prime}$ end of the large-subunit (26S) ribosomal DNA gene, J. Clin. Microbiol. 35 (1997) 1216-1223.

[16] M. Leclerc, C. Delbes, R. Moletta, J.J. Godon, Single strand conformation polymorphism of $16 \mathrm{~S}$ rDNA Archae during start-up of an anaerobic digester, FEMS Microbiol. Ecol. 34 (2001).

[17] H. Lee, Y.G. Zo, S.J. Kim, Non radioactive method to study genetic profiles of natural bacterial communities by PCR-single-strand-conformation polymorphism, Appl. Environ. Microbiol. 62 (1996) 3112-3120.

[18] B.L. Maidak, J.R. Coles, C.T. Parker, G.M. Garrity, N. Larsen, B. Li, T.G. Lilburn, M.J. McCaughey, G.J. Olsen, R. Overbeek, S. Pramanik, T.M. Schmidt, J.M. Tiedje, C.R. Woese, A new version of the RDP (Ribosomal Database Project), Nucl. Acids Res. 27 (1999) 171-173.

[19] S. Pereira-Dias, M.E. Potes, A. Marinho, M. MalfeitoFerreira, V. Loureiro, Characterisation of yeast flora isolated from an artisanal Portuguese ewes' cheese, Int. J. Food Microbiol. 60 (2000) 55-63.

[20] S. Peters, S. Koschinsky, F. Schwieger, C.C. Tebbe, Succession of microbial communities during hot composting as detected by PCR-single-strand-conformationpolymorphism-based genetic profiles of small-subunit rRNA genes, Appl. Environ. Microbiol. 66 (2000) 930-936.

[21] K.M. Petersen, P.L. Moller, L. Jespersen, DNA typing methods for differentiation of Debaryomyces hansenii strains and other yeasts related to surface ripened cheese, Int. J. Food Microbiol. 69 (2001) 11-24.

[22] H. Prillinger, O. Molnar, F. Eliskases-Lechner, K. Lopandic, Phenotypic and genotypic identification of yeasts from cheese, Antonie Van Leeuwenhoek 75 (1999) 267-283.

[23] R. Roostita, G.H. Fleet, The occurrence and growth of yeasts in Camembert and blue-veined cheeses, Int. J. Food Microbiol. 28 (1996) 393-404.

[24] G. Suzzi, A. Lombardi, M.T. Lanorte, M. Caruso, C. Andrighetto, F. Gardini, Phenotypic and genotypic diversity of yeasts isolated from water-buffalo Mozzarella cheese, J. Appl. Microbiol. 88 (2000) 117-123.

[25] M.E. Tornadijo, J.M. Fresno, R.M. Sarmiento, J. Carballo, Study of the yeasts during the ripening process of Armada cheeses from raw goat's milk, Lait 78 (1998) 647-659. 
[26] C.Y. Turenne, E. Witwicki, D.J. Hoban, J.A. Karlowsky, A.M. Kabani, Rapid identification of bacteria from positive blood cultures by fluorescence-based PCRsingle-strand conformation polymorphism analysis of the $16 \mathrm{~S}$ rRNA gene, J. Clin. Microbiol. 38 (2000) 513-520.

[27] J.J. Welthagen, B.C. Viljoen, Yeast profile in Gouda cheese during processing and ripening, Int. J. Food Microbiol. 41 (1998) 185-194.
[28] M. Wojtatowicz, J. Chrzanowska, P. Juszczyk, A. Skiba, A. Gdula, Identification and biochemical characteristics of yeast microflora of Rokpol cheese, Int. J. Food Microbiol. 69 (2001) 135-140.

[29] E. Zumstein, R. Moletta, J.J. Godon, Examination of two years of community dynamics in an anaerobic bioreactor using fluorescence polymerase chain reaction (PCR) single-strand conformation polymorphism analysis, Environ. Microbiol. 2 (2000) 69-78. 